\title{
Hydraulics, Air Entrainment, and Energy Dissipation on a Gabion Stepped Weir
}

\author{
Davide Wüthrich ${ }^{1}$ and Hubert Chanson ${ }^{2}$
}

\begin{abstract}
In the last decades the design of stepped spillways regained some interest because of their suitability with new construction methods including gabions. The hydraulic performances of gabion stepped weirs were investigated experimentally in terms of the flow patterns, air-water flow properties, and energy dissipation. A laboratory study was conducted in a $26.6^{\circ}$ slope (1V:2H) and $0.10-\mathrm{m}$ step height facility, with both smooth impervious and gabion steps. The visual observations highlighted the seepage flow through the gabions, inducing a modification of the cavity flow especially in the skimming flow regime. In skimming flows, higher velocities were measured at the downstream end of the gabion stepped chute, associated with smaller energy dissipation rates and lower friction factors, compared to the smooth impervious stepped chute data. DOI: 10.1061/(ASCE)HY.1943-7900.0000919. () 2014 American Society of Civil Engineers.
\end{abstract}

Author keywords: Gabion weirs; Stepped spillways; Energy dissipation; Air entrainment; Physical modeling.

\section{Introduction}

Stepped spillways and weirs have been used for more than 3,500 years (Chanson 2001). The stepped chute design enhances the rate of energy dissipation on the spillway chute, thus reducing the size and cost of the downstream stilling structure. During the last 3 decades, research into the hydraulics of stepped spillways has been active with a focus on steep stepped spillways for concrete gravity dams (Chanson 1995, 2000; Ohtsu and Yasuda 1998; Minor and Hager 2000). For a given concrete stepped chute, the spill flows as a nappe flow regime for small discharges. For a range of intermediate discharges, a transition flow regime may be observed. Most prototype spillways operate in the skimming flow regime for large flow rates per unit width. In skimming flows, the waters skim as a coherent stream over the pseudobottom formed by step edges and large form losses take place (Rajaratnam 1990).

Stepped spillway flows are characterized by strong flow aeration, very intense turbulence, and interactions between entrained air and turbulence (Chanson and Toombes 2002; Ohtsu et al. 2004). A few studies investigated the impact of macroroughness and turbulence manipulation on skimming flow properties (Andre et al. 2004; Guenther et al. 2013). The effects of step roughness on the flow properties were specifically studied independently by Gonzalez et al. (2008) and Bung and Schlenkhoff (2010) with similar counterintuitive results: i.e., both data sets showed faster flow motion and lesser energy dissipation on rough stepped chutes. Peyras et al. (1992) studied the flow patterns and energy dissipation of gabion stepped weirs, while Kells $(1993,1995)$ discussed the interactions between seepage and free-surface flows on gabion weirs. Fig. 1 shows two photographs of a gabion stepped weir.

\footnotetext{
${ }^{1}$ Research Student, ENAC IIC LCH, Ecole Polytechnique Federale de Lausanne, Lausanne, Switzerland; formerly, Research Student, School of Civil Engineering, Univ. of Queensland, Brisbane QLD 4072, Australia.

${ }^{2}$ Professor in Hydraulic Engineering, Univ. of Queensland, School of Civil Engineering, Brisbane QLD 4072, Australia (corresponding author). E-mail: h.chanson@uq.edu.au

Note. This manuscript was submitted on February 18, 2014; approved on May 6, 2014; published online on June 17, 2014. Discussion period open until November 17, 2014; separate discussions must be submitted for individual papers. This paper is part of the Journal of Hydraulic Engineering, (c) ASCE, ISSN 0733-9429/04014046(10)/\$25.00.
}

A wider literature encompasses the research on riprap overtopping, covering both loose and anchored materials (Judd and Peterson 1969; Knauss 1979; Gerodetti 1981).

It is the purpose of this paper to study thoroughly the hydraulics of gabion stepped weirs, including their air-water flow properties and rate of energy dissipation. A key feature was the systematic comparison between gabion and smooth impervious stepped spillways for a range of flow rates. New measurements were conducted in laboratory with a focus on the transition and skimming flow regimes. The results provided a new understanding of the combined effects of seepage and step surface roughness on the overflow characteristics.

\section{Experimental Facility and Instrumentation}

New experiments were conducted in a relatively large size stepped spillway model at the University of Queensland previously used by Guenther et al. (2013). The test section consisted of a broad-crested weir followed by 10 steps with step height $h=0.1 \mathrm{~m}$ and step length $l=0.2 \mathrm{~m}$. The stepped chute was $0.52-\mathrm{m}$ wide. The water flow was supplied by a large upstream intake basin followed by a smooth sidewall convergent with a 4.23:1 contraction ratio. At the upstream end of the chute, the flow was controlled by a broadcrested weir equipped with an upstream rounded corner. A pump controlled with an adjustable frequency (alternating current) motor drive delivered the flow rate, allowing an accurate discharge adjustment. The water discharge was deduced from the measured upstream head above crest using the discharge calibration results of Felder and Chanson (2012). At the downstream end, the stepped chute was followed by a smooth horizontal channel ending with an overfall. The flow was supercritical in this horizontal tailwater raceway for all investigated flow conditions (Table 1).

Two stepped configurations were tested (Fig. 2). The smooth impervious stepped configuration consisted of flat horizontal steps made of marine ply [Fig. 2(a)]. For the gabion chute, 10 identical gabions were installed above the smooth impervious steps. Each gabion was $0.3-\mathrm{m}$ long, $0.1-\mathrm{m}$ high, and $0.52-\mathrm{m}$ wide, made of fine $12.7 \times 12.7 \mathrm{~mm}^{2}$ galvanized metallic mesh and filled with natural river pebbles [Fig. 2(b)]. The gravels (Cowra pearl) were sieved with 14-mm square sieve. The ratio of stone size to mesh size 


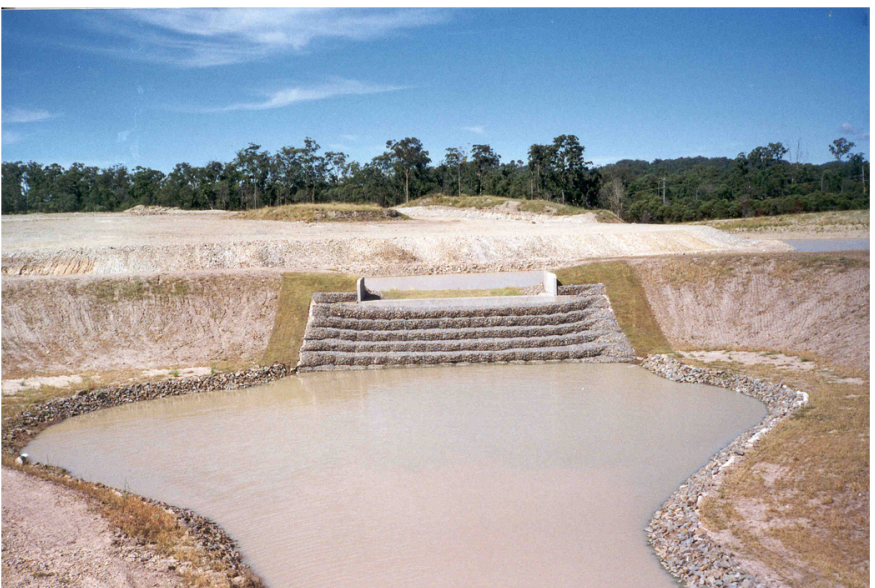

(a)

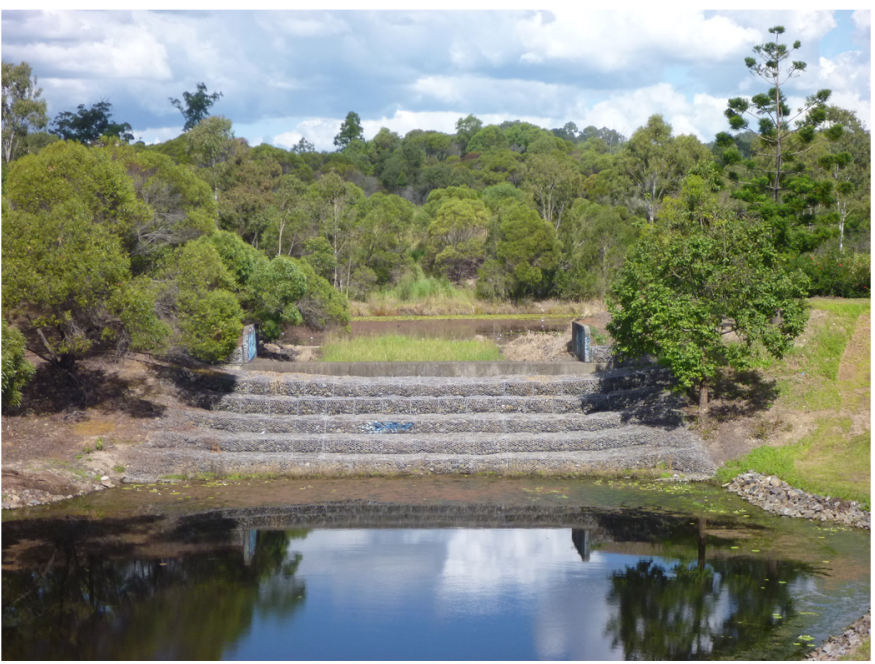

(b)

Fig. 1. Gabion stepped weir at Robina, Gold Coast (Australia), $h=0.6 \mathrm{~m}, l=1.1-2 \mathrm{~m}$ : (a) on April 2, 1997, shortly after completion; (b) on April 25, 2013

was typical of construction practices for more economical cage filling and better adaptability of gabions to deformation (Agostini et al. 1987; Chanson 2001). The density of dry gravels was $1,600 \mathrm{~kg} / \mathrm{m}^{3}$ corresponding to a porosity of $0.35-0.4$. The hydraulic conductivity of the gabions was estimated to be $K \approx 10^{-1} \mathrm{~m} / \mathrm{s}$ (Wüthrich and Chanson 2014).

\section{Instrumentation}

The air-water flow measurements were conducted with a dual-tip phase detection intrusive probe (inner tip diameter of the probe sensor $\varnothing=0.25 \mathrm{~mm}$ ). The probe was mounted on a trolley and the elevation in the direction perpendicular to the pseudobottom formed by the step edges was controlled by a fine adjustment screw-drive mechanism equipped with a Mitutoyo digital ruler (accuracy $0.05 \mathrm{~mm}$ ). The probe was excited by an electronic air bubble detector with a response frequency greater than $100 \mathrm{kHz}$. The probe signal output was sampled at $20 \mathrm{kHz}$ per sensor for $45 \mathrm{~s}$. The main parameters derived from the signal processing were the timeaveraged void fraction $C$, bubble frequency $F$, interfacial velocity $V$, and turbulence intensity $\mathrm{Tu}=v^{\prime} / V$. Further details on the signal postprocessing were discussed in Chanson (2002, 2013). All stepped weir performances, including energy dissipation rate and flow resistance, were calculated based upon the air-water flow measurements.

\section{Flow Conditions}

The experimental study was conducted systematically on the two stepped spillway configurations (Fig. 2). Flow visualisations were carried out for a wide range of discharges within $0.005 \leq$ $Q \leq 0.114 \mathrm{~m}^{3} / \mathrm{s}$. The air-water flow properties were recorded in the transition and skimming flow regimes, for a range of dimensionless discharges between $0.02 \leq Q \leq 0.11 \mathrm{~m}^{3} / \mathrm{s}$ corresponding to dimensionless discharges $0.5 \leq d_{c} / h \leq 1.7$ and Reynolds number $\mathrm{R}$ between $1.4 \times 10^{5}$ and $8.8 \times 10^{5}$, where $d_{c}$ is the critical flow depth $\left[d_{c}=\left(q^{2} / g\right)^{1 / 3}\right] ; q$ is the overflow discharge per unit width measured at the weir crest, and the Reynolds number is defined in terms of the hydraulic diameter. The experimental flow conditions are summarized and compared with previous relevant studies (Table 1).

\section{Flow Regimes}

Visual observations indicated the three classical flow regimes typically observed on stepped spillways for both configurations, as follows: (1) nappe, (2) transition, and (3) skimming flows with increasing flow rates. In addition a porous flow regime was observed on the gabion stepped weir for very low discharges. On the smooth impervious stepped spillway, a nappe flow regime was observed for $d_{c} / h<0.5$. The flow consisted of a succession of free falling nappes from a step to the next step (Chamani and Rajaratnam 1994; Toombes and Chanson 2008). Below each falling nappe a recirculating pool of water was formed with a distinctive air cavity above. For a range of intermediate discharges $\left(0.5<d_{c} / h<0.9\right)$ strong hydrodynamic instabilities associated with a large amount of spray and splashes were observed. The step cavities were almost completely full with a small air pocket under the step edge, while for larger discharges the cavities became filled with water (Chanson and Toombes 2004). For $d_{c} / h>0.9$, the flow skimmed as a coherent stream above the pseudobottom formed by the step edges [Fig. 2(a)]. Substantial air entrainment occurred downstream of the inception point of free surface aeration and an energetic recirculation pattern was observed in the step cavities. Overall the flow pattern observations and flow conditions for the changes between flow regimes were in agreement with the literature (Chanson 2001; Boes and Hager 2003; Felder and Chanson 2009).

On the gabion stepped weir, a porous seepage flow regime was observed for $d_{c} / h<0.3$. All the water seeped through the gabion materials. On the first gabion box, some infiltration was observed [Fig. 3(a)]. A short horizontal seepage face was observed on each step and there was no overflow past the step edges. In the porous material, the free surface (i.e., water table) could be observed through the transparent sidewalls. For the smallest discharges no vertical seepage was observed through the step vertical face. With increasing discharge small water jets came out of the downstream face of the gabions. The transition between porous and nappe flow regime occurred once some overflow took place at the first gabion. For $0.3<d_{c} / h<0.6$, the nappe flow appeared as a succession of free falling nappes from one step edge to the next step edge. The cavity beneath the nappe was filled with a superposition of seepage jets coming out of the upstream gabion [Fig. 3(b)]. In the lower part of the cavity an oscillating recirculation pool was observed. A transition flow regime was observed for $0.6<d_{c} / h<0.9$ [Fig. 2(b)]. The flow instabilities and splashes appeared less intense than those observed on smooth impervious stepped spillway. For the largest discharges a skimming flow was observed $\left(d_{c} / h>0.9\right)$. The flow 
Table 1. Detailed Experimental Investigations on Gabion and Rough Impervious Stepped Weirs

\begin{tabular}{|c|c|c|c|c|c|}
\hline Reference & $\begin{array}{c}\theta \\
\text { (degrees) }\end{array}$ & Geometry & Steps & Flow conditions & Instrumentation \\
\hline \multicolumn{6}{|l|}{ Gabion steps } \\
\hline \multirow[t]{3}{*}{ Peyras et al. (1991) } & 45 & $\begin{array}{l}h=0.2 \mathrm{~m}, l=0.4 \mathrm{~m} \\
W=0.8 \mathrm{~m}\end{array}$ & Gabion steps, plain & $\begin{array}{l}Q=0.05-0.2 \mathrm{~m}^{3} / \mathrm{s} \\
R=2.5 \times 10^{5} \text { to } \\
1.0 \times 10^{6}\end{array}$ & $\begin{array}{l}\text { Pitot tube array, copper pipe } \\
\text { with inlet holes every } 5 \mathrm{~cm}\end{array}$ \\
\hline & 26.6 & & Capped steps, layer cake & & \\
\hline & 18.3 & & Upward steps & & \\
\hline \multirow[t]{2}{*}{ Present study } & 26.6 & $\begin{array}{l}h=0.1 \mathrm{~m}, l=0.2 \mathrm{~m} \\
W=0.52 \mathrm{~m}\end{array}$ & $\begin{array}{l}\text { Pooled steps, end sill } \\
\text { Smooth and } \\
\text { impervious steps }\end{array}$ & $\begin{array}{l}Q=0.02-0.11 \mathrm{~m}^{3} / \mathrm{s} \\
R=1.4 \times 10^{5} \text { to } \\
8.8 \times 10^{5 \mathrm{a}}\end{array}$ & $\begin{array}{l}\text { Double tip conductivity probe, } \\
\varnothing=0.25 \mathrm{~mm}, \Delta x=6.2 \mathrm{~mm} \\
\Delta z=1.35 \mathrm{~mm}\end{array}$ \\
\hline & & & Gabion and porous steps & & \\
\hline \multirow{2}{*}{$\begin{array}{l}\text { Rough impervious steps } \\
\text { Gonzalez et al. (2008) }\end{array}$} & & & & & \\
\hline & 21.8 & $\begin{array}{l}h=0.1 \mathrm{~m}, l=0.25 \mathrm{~m} \\
W=1 \mathrm{~m}\end{array}$ & $\begin{array}{l}\text { Rough impervious step } \\
\text { faces } \\
\text { Rough vertical faces } \\
\text { Rough horizontal faces } \\
\text { Smooth steps }\end{array}$ & $\begin{array}{l}Q=0.01-0.22 \mathrm{~m}^{3} / \mathrm{s} \\
R=5 \times 10^{4} \text { to } 7 \times 10^{5 \mathrm{a}}\end{array}$ & $\begin{array}{l}\text { Double tip conductivity probe, } \\
\emptyset=0.025 \mathrm{~mm}\end{array}$ \\
\hline \multirow[t]{2}{*}{$\begin{array}{l}\text { Bung and } \\
\text { Schlenkhoff (2010) }\end{array}$} & 26.6 & $\begin{array}{l}h=0.06 \mathrm{~m} \\
W=0.30 \mathrm{~m}\end{array}$ & $\begin{array}{l}\text { Rough impervious } \\
\text { horizontal faces, in row }\end{array}$ & $\begin{array}{l}Q=0.021,0.027, \text { and } \\
0.33 \mathrm{~m}^{3} / \mathrm{s} \\
R=2.7 \times 10^{5} \\
3.6 \times 10^{5} ; \text { and } \\
4.4 \times 10^{5 \mathrm{a}}\end{array}$ & $\begin{array}{l}\text { Double-tip conductivity probe, } \\
\emptyset=0.13 \mathrm{~mm}, \Delta x=5.1 \mathrm{~mm}, \\
\Delta y=1 \mathrm{~mm}\end{array}$ \\
\hline & & & $\begin{array}{l}\text { Rough impevious horizontal } \\
\text { faces, shifted } \\
\text { Smooth steps }\end{array}$ & & \\
\hline
\end{tabular}

Note: $h=$ step height; $l=$ step length; $Q=$ water discharge, $\mathrm{R}=$ Reynolds number defined in terms of hydraulic diameter; $W=$ width of channel; $\Delta x=$ streamwise distance between probe tips; $\Delta y=$ vertical distance between probe tips; $\Delta z=$ transverse distance between probe tips; $\emptyset=$ probe diameter; and $\theta=$ chute slope.

${ }^{\mathrm{a}}$ Air-water flow measurements.

pattern was generally similar to that observed on the smooth stepped configuration. However a different streamline pattern was seen next to the stagnation point on the horizontal step face [Fig. 3(c)]. Some bubbly flow and air bubble entrainment into the gabions were observed, mostly in the upper corner of each gabion box downstream of the inception point of free-surface aeration. Visual observations were carried out in the cavity, including with dye injections and wool strings. A vertical flux of air bubbles was observed close to the vertical step face [Fig. 3(c)]. Around the center of the cavity a clear water core was seen downstream of the inception point for all skimming flow discharges in all cavities. The existence of a similar clear water core was previously reported by Gonzalez et al. (2008) for rough impervious steps. Visually the recirculation motion appeared to be modified by the existence of the clear-water core and the interactions with the seepage flow, with the bubbly motion mostly reduced to the downstream end of the cavity [Fig. 3(c)].

At the chute upstream end the water was clear. Further downstream the inception point of free surface aeration was well defined as the location where the turbulence overcame surface tension and air was entrained within the flow. For a given discharge, the position of the inception point was observed to be nearly identical for both stepped configurations. A few air bubbles were seen intermittently up to one to two step cavities upstream of the inception point of free-surface aeration. But their numbers were small and their appearance was irregular. The locations of cavity aeration inception and gabion aeration inception were recorded for the gabion weir. In this paper cavity aeration is defined as the aeration of the (water) cavities beneath the pseudobottom formed by the step edges, while gabion aeration means the air entrainment into the gabion material and is related to the air-water seepage motion. The data indicated that the inception of step cavity aeration and gabion aeration took place about one step cavity downstream of the inception point of free-surface aeration.

For comparison, Peyras et al. (1992) reported two types of flow on gabion stepped weirs, as follows: (1) nappe, and (2) skimming flows, without a mention on seepage and transitions flow regimes. Their observations indicated nappe flows for $d_{c} / h<0.6-0.7$ depending upon the chute slope, with skimming flows for larger flow rates (Peyras et al. 1991).

\section{Air-Water Flow Properties}

\section{Basic Observations}

The air concentration distributions for both smooth impervious and gabion stepped weirs exhibited shapes which were comparable to previous observations on stepped spillways (Chamani and Rajaratnam 1999; Boes and Hager 2003; Felder and Chanson 2009). Fig. 4 shows typical profiles, in which $y$ is the distance normal to the pseudobottom formed by the step edges; and $Y_{90}$ is the characteristic air-water flow depth where the air concentration $C$ equals 0.90. All the data showed substantial flow aeration. In the transition flow regime, the air concentration distributions were compared to a theoretical model (Chanson and Toombes 2002)

$$
C=K^{\prime \prime} \times\left[1-\exp \left(-\lambda \times \frac{y}{Y_{90}}\right)\right]
$$

where $K^{\prime \prime}$ and $\lambda$ are dimensionless functions of the mean air concentration $C_{\text {mean }}$ 


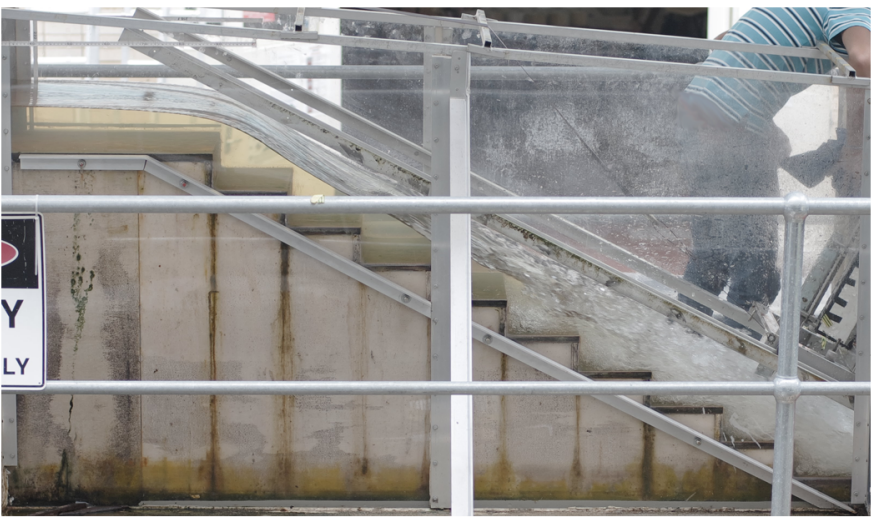

(a)

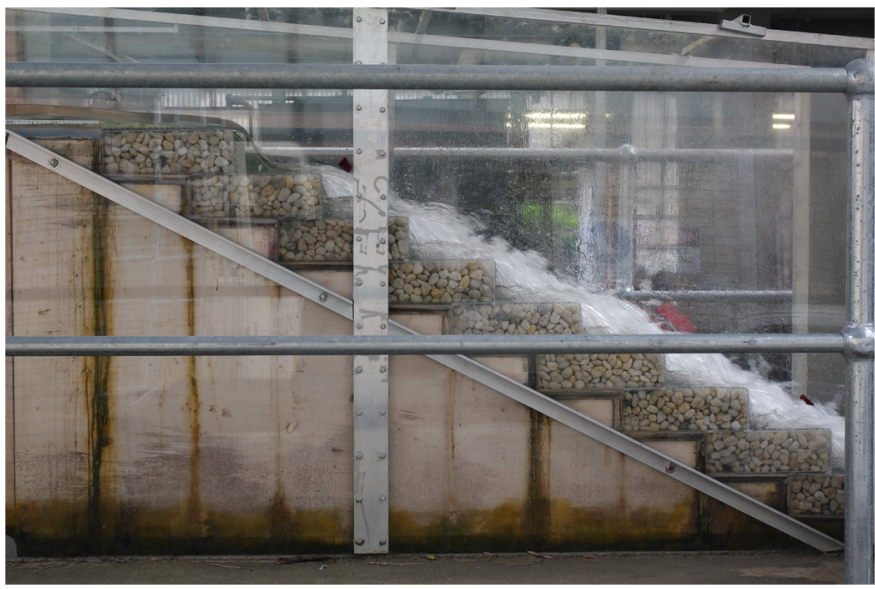

(b)

Fig. 2. Experimental stepped weir: (a) skimming flow on the smooth impervious stepped configuration $\left(d_{c} / h=1.3\right)$; (b) transition flow on the gabion stepped configuration $\left(d_{c} / h \sim 0.9\right)$

$$
\begin{gathered}
K^{\prime \prime}=\frac{0.9}{1-\exp (-\lambda)} \\
\lambda=\frac{0.9}{K^{\prime \prime}-C_{\text {mean }}}
\end{gathered}
$$

Eq. (1) is compared with experimental data [Fig. 4(a)]. The transition flows over gabion steps were observed to be slightly less aerated than the transition flow on the smooth impervious stepped configuration [e.g., Fig. 4(a), steps 8 and 10]. But the air concentration at $y=0$ (i.e., at the gabion edge) was nonzero because of the bubbly flow inside the gabions. In the skimming flows, the air concentration data exhibited an inverted $s$-profile [Fig. 4(b)]. The air concentration distributions were successfully compared with the advective diffusion equation developed by Chanson and Toombes (2002)

$$
C=1-\tan h^{2}\left[K^{\prime}-\frac{\frac{y}{Y_{90}}}{2 \times D_{0}}+\frac{\left(\frac{y}{Y_{90}}-\frac{1}{3}\right)^{3}}{3 \times D_{0}}\right]
$$

where $K^{\prime}$ is an integration constant; and $D_{0}$ is a function of the depth-averaged void fraction $C_{\text {mean }}$

$$
K^{\prime}=0.0327+\frac{1}{2 \times D_{0}}-\frac{8}{81 \times D_{0}}
$$

$$
D_{0}=-\frac{1}{3.614} \times \operatorname{Ln}\left(1.0434-\frac{C_{\text {mean }}}{0.7622}\right)
$$

The results showed a good self-similarity of the void fraction profiles [Fig. 4(b)] and little difference between the two stepped configurations. Eq. (4) is compared with data [Fig. 4(b)].

The bubble frequency distributions on both smooth impervious and gabion stepped spillways showed a marked maximum (Fig. 5) corresponding to a local void fraction between 0.4 and 0.5 . The results were consistent with previous studies on stepped spillways with smooth impervious steps (Toombes 2002; Gonzalez 2005). In Fig. 5, typical results are presented in terms of the dimensionless bubble frequency $F \times d_{c} / V_{c}$ where $F$ is the number of bubbles detected per unit time; and $V_{c}$ is the critical flow velocity, i.e., $V_{c}=$ $\sqrt{g \times d_{c}}$. For all discharges, the bubble frequency was consistently smaller on the gabion stepped weir compared to the smooth impervious stepped chute. In the skimming flows, some difference was noted between smooth and gabion stepped chutes in the lower part of the flow; namely, significantly less bubble counts were recorded in the gabion stepped configuration [Fig. 5(b)]. This finding is still not fully understood although it is conceivable that the discharge seeping through the gabions altered the vortex shedding downstream of the step edges, leading to lesser turbulent stress levels.

The velocity distributions showed self-similar profiles. In skimming flows, the smooth impervious and gabion chute data compared favorably with a power law for $y<Y_{90}$ and an uniform profile above

$$
\begin{gathered}
\frac{V}{V_{90}}=\left(\frac{y}{Y_{90}}\right)^{1 / N} \quad 0 \leq \frac{y}{Y_{90}} \leq 1 \\
\frac{V}{V_{90}}=1 \quad \frac{y}{Y_{90}} \geq 1
\end{gathered}
$$

where $V_{90}=$ interfacial velocity at $y=Y_{90}$ (i.e., $C=0.9$ ). Fig. 6 shows typical velocity distributions and the data are compared with Eqs. (7a) and (7b) for an exponent $N=8$. The same self-similar shape was observed on both configurations. But the gabion stepped chute flow exhibited faster velocities than the smooth impervious stepped chute flow, for the same discharge at the same location downstream of the inception point of free-surface aeration (Fig. 6). Given the increased roughness of the gabion steps the finding was counterintuitive, although a similar trend was previously observed on rough impervious steps by Gonzalez et al. (2008) and Bung and Schlenkhoff (2010). It is plausible that in skimming flows the recirculation flow was altered by a combined effect of gabion seepage outflow into step cavities and step surface roughness. The former effect was documented in monophase flow, sometimes termed (monophase flow) ventilation (Wood 1964; Naudascher and Rockwell 1994), while the latter was linked to turbulence manipulation, for example observed with riblets and $d$-type roughness in developing boundary layer (Djenidi and Antonia 1995; Djenidi et al. 1999).

For both smooth impervious and gabion stepped configurations, the turbulence intensity distributions presented a local maximum at the elevation where the bubble count rate was maximum. Fig. 7 shows typical results in transition and skimming flows. Overall the level of turbulence was higher on the smooth impervious stepped chute for transition and skimming flows. The results suggested that the interactions between seepage and overflow contributed to some dampening of the free-surface flow turbulence. 


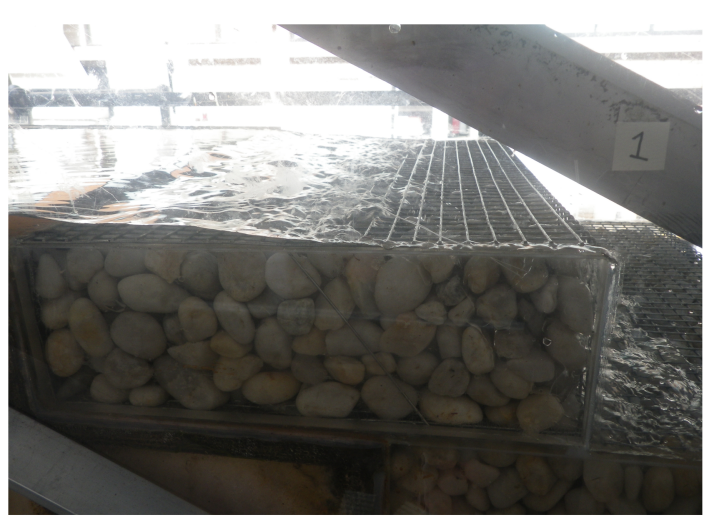

(a)

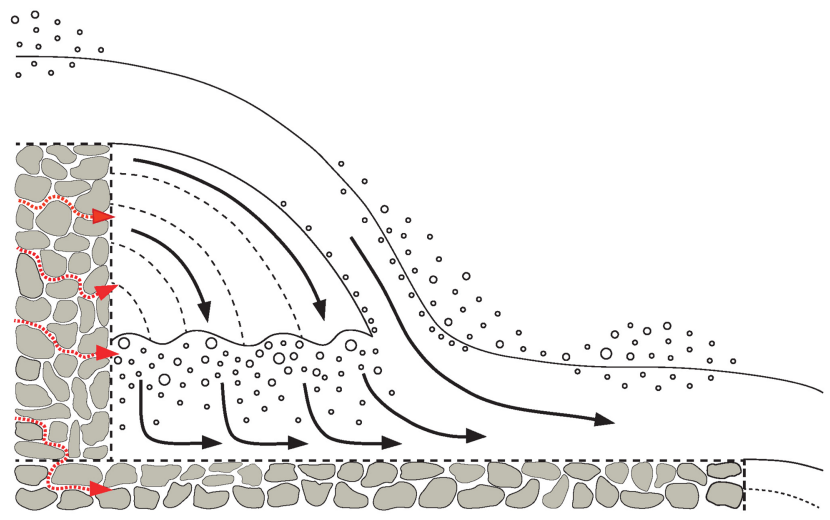

(b)

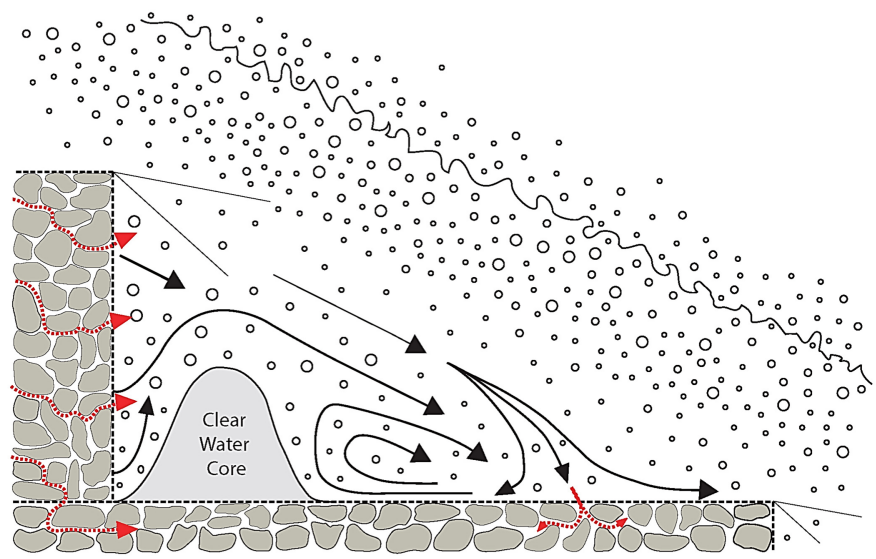

(c)

Fig. 3. Porous, nappe, and skimming flow regimes above a gabion stepped weir: (a) porous flow at first gabion box located at end of broad-crest, $d_{c} / h=0.20, Q=0.005 \mathrm{~m}^{3} / \mathrm{s}, \mathrm{R}=3.5 \times 10^{4}$; (b) nappe flow; (c) skimming flow
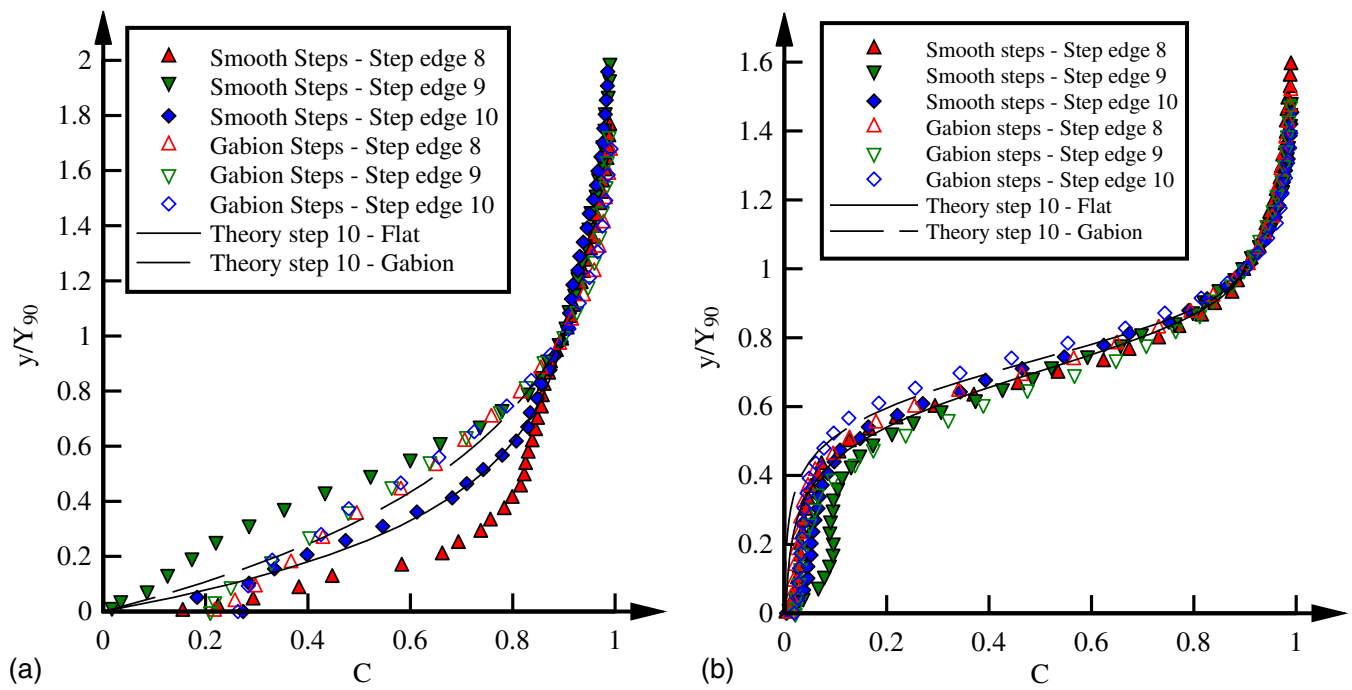

Fig. 4. Air concentration distributions in transition and skimming flows on smooth impervious and gabion stepped weirs, $\theta=26.6^{\circ}, h=0.10 \mathrm{~m}$ : (a) $d_{c} / h=0.5, Q=0.018 \mathrm{~m}^{3} / \mathrm{s}, R=1.40 \times 10^{5}$; (b) $d_{c} / h=1.3, Q=0.076 \mathrm{~m}^{3} / \mathrm{s}, \mathrm{R}=5.9 \times 10^{5}$

\section{Longitudinal Air-Water Flow Properties}

Fig. 8 shows the longitudinal distributions of selected characteristic air-water properties, namely the characteristic flow depth $Y_{90}$, the depth averaged void fraction $C_{\text {mean }}$, and the characteristic air-water flow velocity $V_{90}$. The results are plotted in dimensionless form in terms of the step edge. The step edge 1 was the first step edge at the downstream end of the broad crest and the measurement location 11 was set in the horizontal tailrace channel at 0.2-m downstream of step edge 10. For all flow conditions, the results showed that the air-water flow height was lower on the gabion stepped weir and 

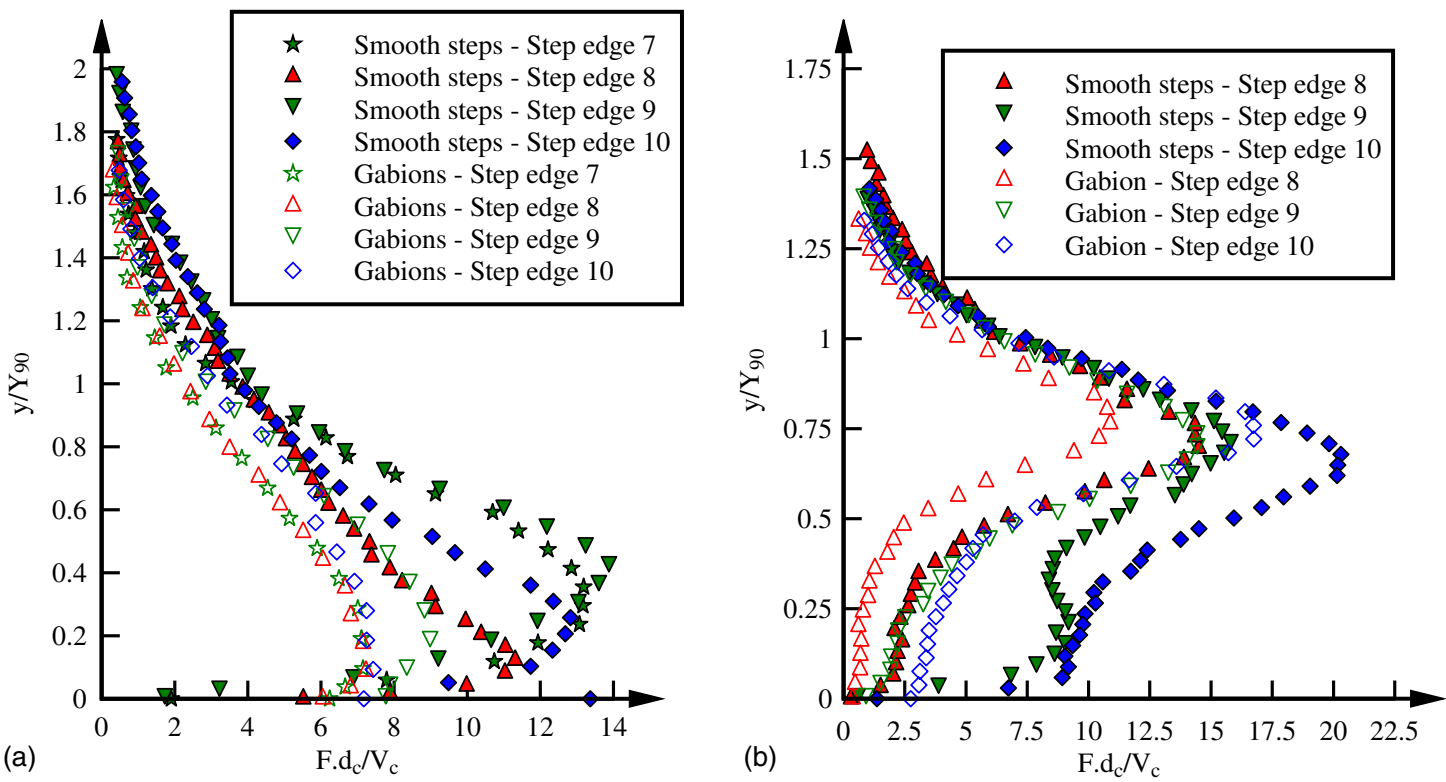

Fig. 5. Bubble count rate distributions in transition and skimming flows on smooth impervious and gabion stepped weirs, $\theta=26.6^{\circ}, h=0.10 \mathrm{~m}$ : (a) $d_{c} / h=0.5, Q=0.018 \mathrm{~m}^{3} / \mathrm{s}, \mathrm{R}=1.40 \times 10^{5}$; (b) $d_{c} / h=1.5, Q=0.095 \mathrm{~m}^{3} / \mathrm{s}, \mathrm{R}=7.3 \times 10^{5}$

this was consistent with photographic observations. The depthaveraged void fraction data $C_{\text {mean }}$ highlighted a lesser aeration of the flow on the gabion stepped configuration. At step edge 10, $C_{\text {mean }}$ was between $1.0 \times$ and $1.4 \times$ larger on the smooth impervious stepped chute than on the gabion stepped chute, and the difference increased monotonically with an increasing discharge (Fig. 8). The characteristic air-water velocity $V_{90} / V_{c}$ data showed that in the

\begin{tabular}{|c|c|c|c|c}
\cline { 2 - 5 } \multicolumn{1}{c|}{} & \multicolumn{2}{c|}{ Smooth impervious } & \multicolumn{2}{c}{ Gabion } \\
\hline Step edge & $\mathrm{Y}_{90}(\mathrm{~m})$ & $\mathrm{V}_{90}(\mathrm{~m} / \mathrm{s})$ & $\mathrm{Y}_{90}(\mathrm{~m})$ & $\mathrm{V}_{90}(\mathrm{~m} / \mathrm{s})$ \\
\hline 8 & 0.075 & 3.26 & 0.054 & 3.75 \\
\hline 9 & 0.078 & 3.39 & 0.058 & 3.87 \\
\hline 10 & 0.074 & 3.56 & 0.057 & 4.0 \\
\hline
\end{tabular}

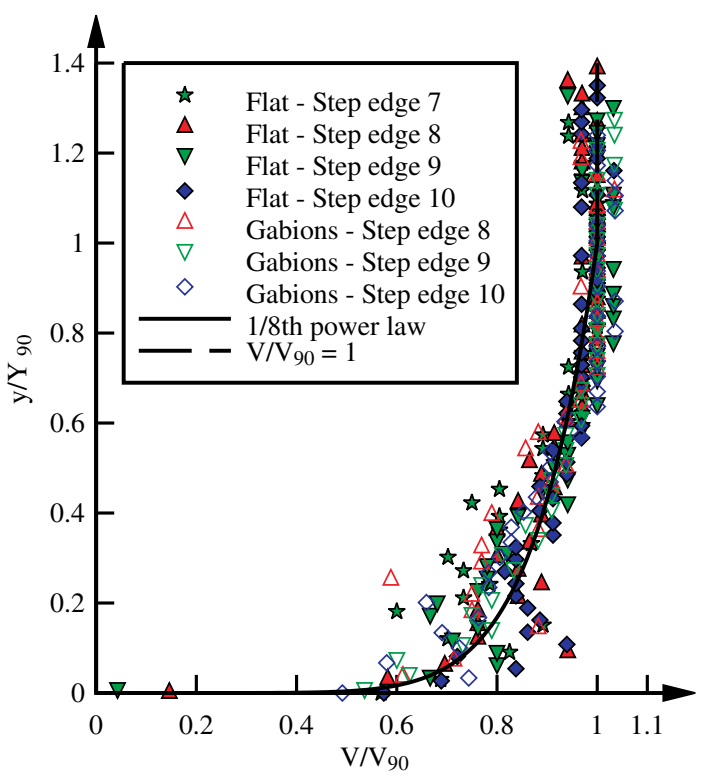

Fig. 6. Velocity distributions in skimming flow on smooth impervious and gabion stepped weirs, $\theta=26.6^{\circ}, h=0.10 \mathrm{~m}, d_{c} / h=1.3, Q=$ $0.076 \mathrm{~m}^{3} / \mathrm{s}, \mathrm{R}=5.9 \times 10^{5}$, comparison with a one-eighth profile skimming flow regime $V_{90}$ was larger on the gabion weir. Although counterintuitive, these results were similar to the findings on rough impervious steps (per the previous discussion).

The porosity of gabion steps induced some seepage through the gabions, thus reducing the overflow discharge above the steps. The overflow discharge per unit width above the gabions $q_{w}$ was estimated based upon the equation of conservation of mass using the measured air-water flow properties

$$
q_{w}=\int_{0}^{Y_{90}}(1-C) \times V \times d y
$$

The data showed that the proportion of seepage flow $\left(1-q_{w} / q\right)$ was a function of the flow regime and flow rate. In nappe flow conditions, the seepage flow ratio was about 0.5 on average. In skimming flows, $\left(1-q_{w} / q\right)$ was down to $0.05-0.15$.

\section{Energy Dissipation Performances}

The rate of energy dissipation and flow resistance above the stepped weir were calculated based upon the air-water flow measurements. For the smooth impervious stepped weir, all calculations were based upon the total discharge $q$ measured at the weir crest. For the gabion stepped chute, the flow resistance calculations were performed using the overflow discharge $q_{w}$ [Eq. (8)].

For design purposes, a key parameter is the residual head estimated as

$$
H_{\mathrm{res}}=\int_{0}^{Y_{90}}(1-C) \times d y \times \cos \theta+\frac{q^{2}}{2 \times g \times\left[\int_{0}^{Y_{90}}(1-C) \times d y\right]^{2}}
$$

Fig. 9 summarizes the results, regrouping the data measured at the last step edge (step 10) and in the bottom tailrace channel 0.20 -m downstream of step edge 10. The experimental results showed that the gabion stepped weir was the least efficient in terms of energy dissipation except for the smallest discharge. The largest residual head was observed with the gabion stepped chute 

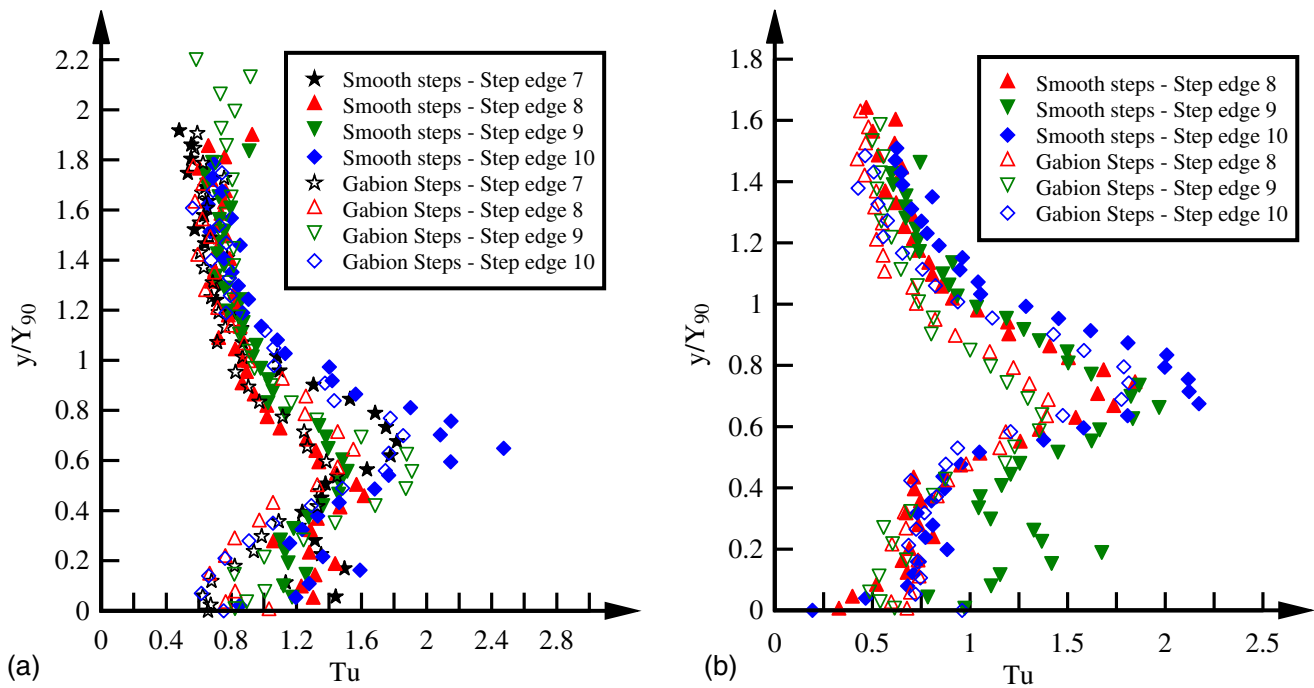

Fig. 7. Turbulence intensity distributions in transition and skimming flow in smooth impervious and gabion stepped weirs, $\theta=26.6^{\circ}, h=0.10 \mathrm{~m}$ : (a) $d_{c} / h=0.8, Q=0.037 \mathrm{~m}^{3} / \mathrm{s}, \mathrm{R}=2.83 \times 10^{5}$; (b) $d_{c} / h=1.1, Q=0.059 \mathrm{~m}^{3} / \mathrm{s}, \mathrm{R}=4.57 \times 10^{5}$
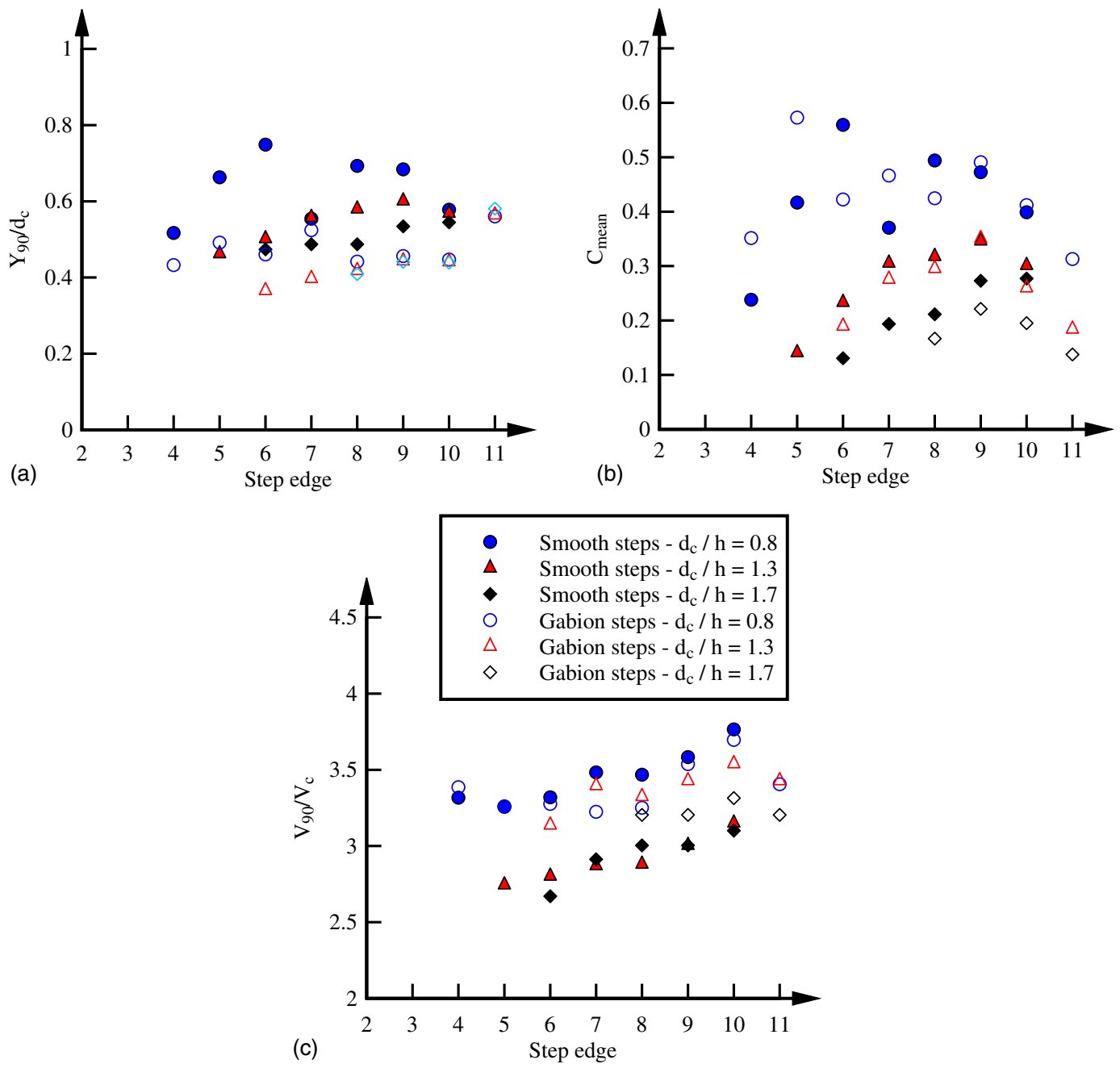

Fig. 8. Longitudinal distributions of characteristic air-water flow properties $Y_{90} / d_{c}, C_{\text {mean }}$, and $V_{90} / V_{c}$ for smooth impervious and gabion stepped weirs $\left(\theta=26.6^{\circ}, h=0.10 \mathrm{~m}\right)$, same legend applies to all graphs 


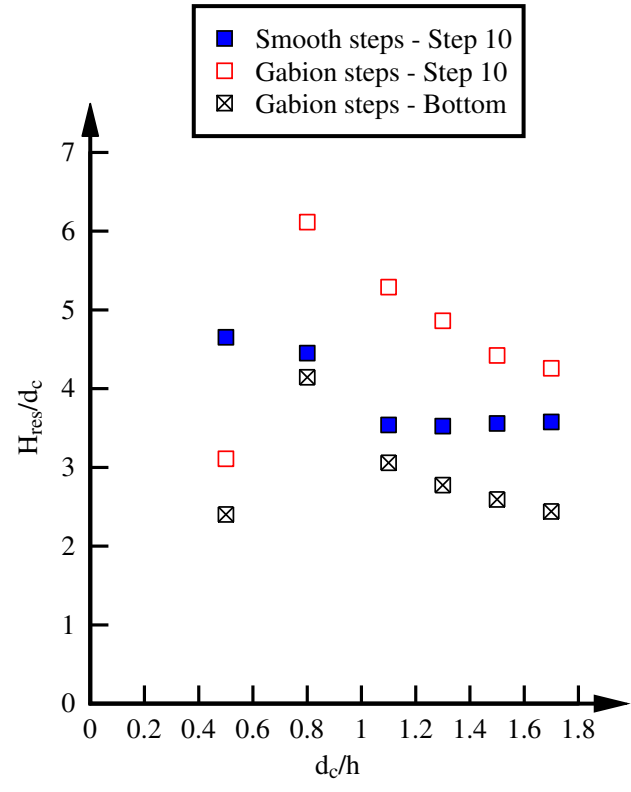

Fig. 9. Residual head at the downstream end of smooth impervious and gabion stepped chutes $\left(\theta=26.6^{\circ}, h=0.10 \mathrm{~m}\right)$, gabion data measured at step edge 10 and in bottom (tailrace) channel

in skimming flows (Fig. 9). For the smallest flow rate, on the other hand, the gabion stepped chute flow presented the smallest residual head. Between the step edge 10 and the tailrace channel some differences in terms of energy dissipation were seen for the gabion stepped chute which reflected likely the large energy dissipation rate of the seepage flow component (Stephenson 1979).

The flow resistance was evaluated in terms of the DarcyWeisbach friction factor (Rajaratnam 1990; Chanson 2001). The friction factor was calculated based upon the air-water flow properties and total head line slope measurements

$$
f_{e}=\frac{8 \times g \times S_{f} \times\left[\int_{0}^{Y_{90}}(1-C) \times d y\right]}{\left[q / \int_{0}^{Y_{90}}(1-C) \times d y\right]^{2}}
$$

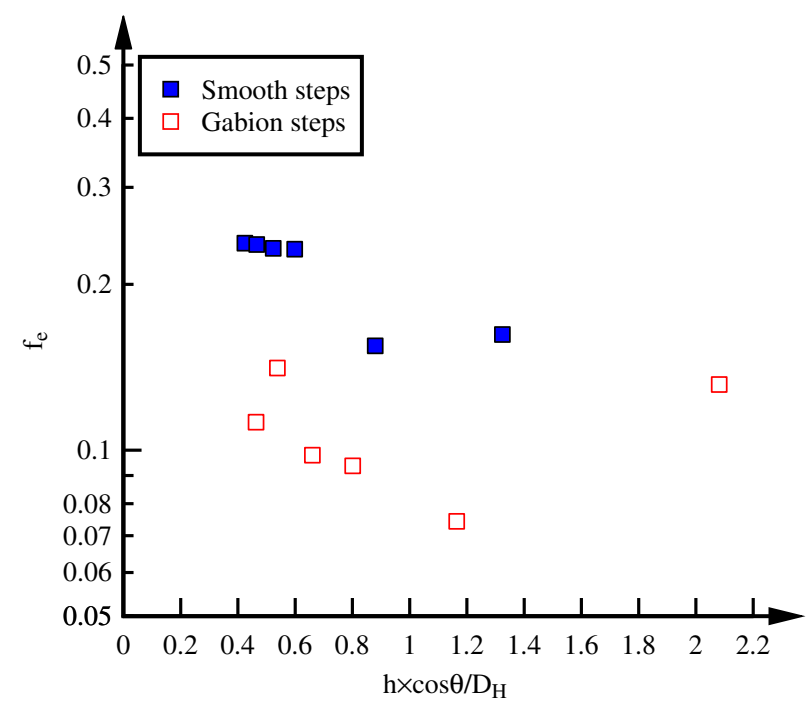

Fig. 10. Equivalent Darcy-Weisbach friction factor on smooth impervious and gabion stepped weirs $\left(\theta=26.6^{\circ}, h=0.10 \mathrm{~m}\right)$ where $S_{f}=$ total head line slope, i.e., $S_{f}=-\partial H / \partial x$, where $H=$ total head; and $x=$ distance in flow direction. Fig. 10 shows the present data as a function of the dimensionless step roughness height $h \times \cos \theta / D_{H}$, where $D_{H}$ is the hydraulic diameter. The results indicated consistently that the smallest flow resistance was experienced on the gabion stepped chute (Fig. 10). On the smooth impervious stepped weir, the flow resistance was on average $2 \times$ larger than that on the gabion stepped chute for the investigated flow conditions and the results were within commonly accepted values for stepped spillways (Chanson 2006). In the skimming flow regime, the average Darcy-Weisbach friction factor was 0.23 for the smooth impervious steps and 0.11 for the gabion steps.

Although the gabion step faces were much rougher, the present results showed that in skimming flows the gabion stepped design was the least efficient in terms of energy dissipation performances and flow resistance. The finding was unexpected, but in qualitative agreement with the results of Gonzalez et al. (2008) and Bung and Schlenkhoff (2010) on rough impervious steps.

\section{Conclusion}

The hydraulic performances of a gabion stepped weir were investigated with a systematic comparison of the performances of gabion and smooth impervious stepped chutes with a slope of $26.6^{\circ}$ $(1 \mathrm{~V}: 2 \mathrm{H})$ and step height of $0.1 \mathrm{~m}$. For each configuration, the detailed flow properties were investigated for a wide range of discharges. The visual observations highlighted the seepage flow through the gabions. On the gabion stepped chute, a porous regime was observed for the smallest discharges; there was no overflow and the water seeped through the gabions. For larger discharges, the main overflow regimes included the nappe, transition, and skimming flows with increasing discharges. The interactions between seepage flow and overflow were functions of the discharge, gabion configuration, and flow regime, and they resulted in a modification of the step cavity flow and recirculation patterns. The seepage flow motion was observed to cause a modification of the cavity flow dynamics, while a substantial number of air bubbles were entrapped in the gabions.

The air-water flow measurements showed comparable trends for both stepped weirs, although with some quantitative differences. The gabion stepped chute was slightly less aerated, while the bubble count rate and turbulence intensity were lower on the gabion stepped weir. In skimming flows larger velocities were measured at the downstream end of the gabion stepped weir. The rate of energy dissipation and residual head data showed that the rate of energy dissipation was the lowest on the gabion stepped weir. While the finding might appear counterintuitive, it was consistent with previous experimental results on rough impervious stepped chutes, highlighting the importance of sound physical modeling in the investigation of hydraulic structures. It is hypothesized that the cavity recirculation motion was altered by a combined effect of gabion seepage discharging into step cavities and step surface roughness, thus reducing the flow resistance and rate of energy dissipation above the gabion stepped chute. The laboratory experiments were conducted with new gabion boxes. The weir structure was possibly more rigid than older gabion structures [Fig. 1(b)] and it was not affected by any form of settlement and damage.

\section{Acknowledgments}

The writers acknowledge the people who assisted with the experiments and the technical staff of the School of Civil Engineering at the University of Queensland. The financial support of 
the Australian Research Council (Grant DP120100481) is acknowledged.
90 flow properties at the characteristic location where $C=0.90$.

\section{Notation}

The following symbols are used in this paper:

$C=$ air concentration, defined as the volume of air per unit volume;

$C_{\text {mean }}=$ depth-averaged air concentration defined in terms of $Y_{90}, C_{\text {mean }}=1-\left(d / Y_{90}\right)$;

$D_{H}=$ hydraulic diameter $(\mathrm{m})$;

$D_{o}=$ constant function of the mean void fraction in the advective diffusion equation (skimming flow);

$d=$ equivalent clear water flow depth $(\mathrm{m})$ defined as $d=\int_{y=0}^{Y_{90}}(1-C) \times d y$;

$d_{c}=$ critical flow depth $(\mathrm{m}), d_{c}=\left(q^{2} / g\right)^{1 / 3}$;

$F=$ bubble frequency $(\mathrm{Hz})$ defined as the number of detected air bubbles per unit time;

$g=$ gravity constant $\left(\mathrm{m} / \mathrm{s}^{2}\right), g=9.794 \mathrm{~m} / \mathrm{s}^{2}$ in Brisbane (Australia);

$H=$ total head $(\mathrm{m}), H=z_{o}+\int_{0}^{Y_{90}}(1-C) \times d y \times \cos \theta$ $+\frac{q^{2}}{2 \times g \times\left[\int_{0}^{Y_{90}}(1-C) \times d y\right]^{2}} ;$

$H_{\text {res }}=$ residual head of the flow $(\mathrm{m})$;

$h=$ vertical step height $(\mathrm{m})$;

$K=$ hydraulic conductivity of a porous medium $(\mathrm{m} / \mathrm{s})$;

$K^{\prime}=$ integration constant in the advective diffusion equation (skimming flow);

$K^{\prime \prime}=$ integration constant in the advective diffusion equation (transition flow);

$l=$ horizontal step length $(\mathrm{m})$;

$Q=$ overflow discharge $\left(\mathrm{m}^{3} / \mathrm{s}\right)$ measured at the weir crest;

$q=$ overflow discharge per unit width $\left(\mathrm{m}^{2} / \mathrm{s}\right)$ measured at the weir crest, defined as $q=Q / W$;

$q_{w}=$ water discharge per unit width $\left(\mathrm{m}^{2} / \mathrm{s}\right)$ calculated from the integration of the void ratio and velocity profiles, $q_{w}=\int_{y=0}^{Y_{90}}(1-C) \times V \times d y ;$

$\mathrm{R}=$ Reynolds number defined in terms of the hydraulic diameter;

$S_{f}=$ friction slope defined as $S_{f}=-\partial H / \partial x$;

$\mathrm{Tu}=$ turbulence intensity, $\mathrm{Tu}=u^{\prime} / V$;

$u^{\prime}=$ RMS of velocity fluctuations $(\mathrm{m} / \mathrm{s})$;

$V=$ time-averaged interfacial velocity $(\mathrm{m} / \mathrm{s})$;

$V_{c}=$ critical velocity of the flow $(\mathrm{m} / \mathrm{s})$ defined as $V_{c}=\left(g \times d_{c}\right)^{1 / 2}$;

$V_{90}=$ characteristic interfacial velocity $(\mathrm{m} / \mathrm{s})$ where $C=0.9$;

$W=$ width of the stepped spillway $(\mathrm{m})$;

$x=$ longitudinal distance $(\mathrm{m})$ measured along the pseudobottom formed by the step edges;

$Y_{90}=$ characteristic depth $(\mathrm{m})$ where $C=0.9$;

$y=$ distance $(\mathrm{m})$ measured perpendicular to the pseudobottom formed by the step edges;

$z_{o}=$ bed elevation $(\mathrm{m})$ above the tailwater channel invert;

$\Delta x=$ streamwise distance between the probe tips $(\mathrm{m}) ;$

$\Delta z=$ transverse distance between the probe tips (m);

$\varnothing=$ diameter of the probe sensor $(\mathrm{m})$;

$\lambda=$ dimensionless function of the mean air concentration (transition flow); and

$\theta=$ chute slope, $\tan \theta=h / l$.

\section{Subscripts}

$c=$ critical flow conditions; and

\section{References}

Agostini, R., Bizzarri, A., Masetti, M., and Papetti, A. (1987). "Flexible gabion and reno mattress structures in river and stream training works. Section one: Weirs." Officine maccaferri, 2nd Ed., Bologna, Italy.

Andre, S., Boillat, J. L., Schleiss, A. J., and Matos, J. (2004). "Energy dissipation and hydrodynamic forces of aerated flow over macroroughness linings for overtopped embankment dams." Proc., Intl Conf. on Hydraulics of Dams and River Structures, Balkema, Rotterdam, Netherlands, 189-196.

Boes, R. M., and Hager, W. H. (2003). "Two-phase flow characteristics of stepped spillways." J. Hydraul. Eng., 10.1061/(ASCE)0733-9429 (2003)129:9(661), 661-670.

Bung, D. B., and Schlenkhoff, A. (2010). "Self-aerated flow on embankment stepped spillways-The effect of additional micro-roughness on energy dissipation and oxygen transfer." Proc., IAHR European Congress (CD-ROM), International Association for Hydro-Environment Engineering and Research, Munich, Germany.

Chamani, M. R., and Rajaratnam, N. (1994). "Jet flow on stepped spillways.” J. Hydraul. Eng., 10.1061/(ASCE)0733-9429(1994)120:2(254), 254-259.

Chamani, M. R., and Rajaratnam, N. (1999). "Characteristics of skimming flow over stepped spillways.” J. Hydraul. Eng., 10.1061/(ASCE)0733 -9429(1999)125:4(361), 361-368.

Chanson, H. (1995). Hydraulic design of stepped cascades, channels, weirs and spillways, Pergamon, Oxford, U.K.

Chanson, H. (2000). "Hydraulics of stepped spillways: Current status (Forum article)." J. Hydraul. Eng., 10.1061/(ASCE)0733-9429(2000) 126:9(636), 636-637.

Chanson, H. (2001). The hydraulics of stepped chutes and spillways, Balkema, Rotterdam, Netherlands.

Chanson, H. (2002). "Air-water flow measurements with intrusive phasedetection probes. Can we improve their interpretation?" J. Hydraul. Eng., 10.1061/(ASCE)0733-9429(2002)128:3(252), 252-255.

Chanson, H. (2006). "Hydraulics of skimming flows on stepped chutes: The effects of inflow conditions?" J. Hydraul. Res., 44(1), 51-60.

Chanson, H. (2013). "Hydraulics of aerated flows: Qui pro quo?" J. Hydraul. Res., 51(3), 223-243.

Chanson, H., and Toombes, L. (2002). "Air-water flows down stepped chutes: Turbulence and flow structure observations." Int. J. Multiphase Flow, 28(11), 1737-1761.

Chanson, H., and Toombes, L. (2004). "Hydraulics of stepped chutes: The transition flow." J. Hydraul. Res., 42(1), 43-54.

Djenidi, L., and Antonia, R. A. (1995). "Riblet modelling using a secondmoment closure." Appl. Sci. Res., 54(4), 249-266.

Djenidi, L., Elavarasan, R., and Antonia, R. A. (1999). "The turbulent boundary layer over transverse square cavities.” J. Fluid Mech., 395, 271-294.

Felder, S., and Chanson, H. (2009). "Energy dissipation, flow resistance and gas-liquid interfacial area in skimming flows on moderate-slope stepped spillways." Environ. Fluid Mech., 9(4), 427-441.

Felder, S., and Chanson, H. (2012). "Free-surface profiles, velocity and pressure distributions on a broad-crested weir: A physical study." J. Irrig. Drain. Eng., 10.1061/(ASCE)IR.1943-4774.0000515, 1068-1074.

Gerodetti, M. (1981). "Model studies of an overtopped rockfill dam.” Water Power Dam Constr., 34(9), 25-31.

Gonzalez, C. (2005). "Experimental study of free-surface aeration on embankment stepped chutes." Ph.D. thesis, Dept. of Civil Engineering, Univ. of Queensland, Brisbane, Australia.

Gonzalez, C., Takahashi, M., and Chanson, H. (2008). "An experimental study of effects of step roughness in skimming flows on stepped chutes." J. Hydraul. Res., 46(1), 24-35.

Guenther, P., Felder, S., and Chanson, H. (2013). "Flow aeration, cavity processes and energy dissipation on flat and pooled stepped spillways for embankments." Environ. Fluid Mech., 13(5), 503-525. 
Judd, H. E., and Peterson, D. F. (1969). "Hydraulics of large bed element channels." Utah Water Research Laboratory Research Rep., PRWG 17-6, Utah State Univ., Logan, UT.

Kells, J. A. (1993). "Spatially varied flow over rockfill embankments." Can. J. Civil Eng., 20(5), 820-827.

Kells, J. A. (1995). "Comparison of energy dissipation between nappe and skimming flow regimes on stepped chutes-Discussion." J. Hydraul. Res., 33(1), 128-133.

Knauss, J. (1979). "Computation of maximum discharge at overflow rockfill dams (a comparison of different model test results)." Proc., 13th ICOLD Congress, International Congress on Large Dams, 143-159.

Minor, H. E., and Hager, W. H. (2000). "Hydraulics of stepped spillways." Proc., Int. Workshop on Hydraulics of Stepped Spillways, Balkema, Rotterdam, Netherlands.

Naudascher, E., and Rockwell, D. (1994). "Flow-induced vibrations. An engineering guide." IAHR hydraulic structures design manual no. 7. Hydraulic design considerations, Balkema, Rotterdam, Netherlands.

Ohtsu, I., and Yasuda, Y. (1998). "Hydraulic characteristics of stepped channel flows." Workshop on Flow Characteristics around Hydraulic Structures and River Environment, University Research Center, Nihon Univ., Tokyo, Japan, 55.

Ohtsu, I., Yasuda, Y., and Takahashi, M. (2004). "Flow characteristics of skimming flows in stepped channels." J. Hydraul. Eng., 10.1061/ (ASCE)0733-9429(2004)130:9(860), 860-869.
Peyras, L., Royet, P., and Degoutte, G. (1991). "Ecoulement et dissipation sur les déversoirs en gradins de gabions [Flows and dissipation of energy on gabion weirs]." $\mathrm{Jl} \mathrm{La}$ Houille Blanche, 1, 37-47 (in French).

Peyras, L., Royet, P., and Degoutte, G. (1992). "Flow and energy dissipation over stepped gabion weirs." J. Hydraul. Eng., 10.1061/(ASCE) 0733-9429(1992)118:5(707), 707-717.

Rajaratnam, N. (1990). "Skimming flow in stepped spillways." J. Hydraul. Eng., 10.1061/(ASCE)0733-9429(1990)116:4(587), 587-591.

Stephenson, D. (1979). "Gabion energy dissipators." Proc., 13th ICOLD Congress, International Congress on Large Dams, 33-43.

Toombes, L. (2002). "Experimental study of air-water flow properties on low-gradient stepped cascades." Ph.D. thesis, School of Civil Engineering, Univ. of Queensland, Brisbane, Australia.

Toombes, L., and Chanson, H. (2008). "Flow patterns in nappe flow regime down low gradient stepped chutes." J. Hydraul. Res., 46(1), 4-14.

Wood, C. J. (1964). "The effect of base bleed on periodic wake." J. Roy. Aeronaut. Soc., 68, 477-482.

Wüthrich, D., and Chanson, H. (2014). "Aeration and energy dissipation over stepped gabion spillways: A physical study." Hydraulic Model Rep. No. CH92/13, School of Civil Engineering, Univ. Queensland, Brisbane, Australia. 